\title{
INSTRUCTIONAL DESIGN FOR STUDENTS WITH VISUAL IMPAIRMENTS IN ENGLISH LEARNING
}

\author{
Rizki Farani \\ Widya Aryanti \\ State Islamic University (UIN) Sunan Kalijaga
}

\begin{abstract}
Mastering English has become one important skill for students in higher education, especially in university level. As the impact, every university provides English program for students in the faculty or language center. However, not every student can master English fast, for example: students with visual impairments. Students with visual impairment are a group of students who have visual problem; either it is low vision or blind. Students with visual impairment need different approach in learning English. This condition motivates lectures to adapt specific instructional design to support classroom activities.

There are 4 important components in designing instructional design for students with visual impairment, such as students' characteristics, learning objective, method and assessment. The design should be adapted to fully support their inclusion in the classroom. By designing instructional design for students with visual impairments, it is expected that they will be able to comprehend the material and to increase their motivation in learning English.

This paper aimed to understand appropriate instructional design for students with visual impairment. This paper also provides study cases in Inclusion English Class at university level where students with visual impairment and sighted students study at the same classroom. By discussing this issue, it is expected that every lecture recognize basic characteristics of students with visual impairment and choose the appropriate instructional design to accommodate all character of students.
\end{abstract}


Keywords : instructional design, visual impairment, English learning

\section{INTRODUCTION}

Nowadays, English learning is known widely in every level of education, especially university level. English skills are considered as one competency in college education. Mastering English is expected to support academic activities such as finding resources, writing papers or presentations.

However, presenting English material in the classroom can be a challenge for lectures when the students have special need, for example: visual impairments. They have different needs compared to sighted students. They ought to get a different teaching learning process. Certain teaching strategies suitable for learners without sight difficulties might not be proper for learners with visual impairment. For example, asking students to watch movies to teach certain language features in class might not be suitable for since they cannot see the movies. Therefore, lectures should design specific instructional design to support their inclusion in the classroom. The instructional design should present several aspects such as relevant content, appropriate media and appropriate approach. By designing specific instructional design for them, it is expected that their motivation, self-esteem and independence will be improved.

This paper aimed to understand the appropriate instructional design for students with visual impairment in English learning class.

\section{LITERATURE REVIEW}

\section{Students with Visual Impairments}

Students with visual impairment are a group of students who have visual problems. Commonly, people could say this condition as blind. There are two main categories of visual impairments, i.e.: low vision and blind. According to Carney, et.al (2001: 7), most students with visual impairments have low vision. These students should encouraged to use their residual (remaining) vision, when appropriate, using the necessary optical aids and adaptations. On the other hand, blind students range from being totally without sight to unreliable vision and primary reliance on other senses. A person with blindness usually uses Braille as a reading and writing medium

Meanwhile, WHO divided four levels of visual function, according to the 
International Classification of Diseases -10 (Update and Revision 2006): (1) normal vision; (2) moderate visual impairment; (3) severe visual impairment and (4) blindness. Moderate visual impairment combined with severe visual impairment is grouped under the term "low vision": low vision taken together with blindness represents all visual impairment. Similarly, Manal (2012: 1) also stated that here are four categories of visual impairment: (1) partially sighted, (2) low vision, (3) legally blind and (4) totally blind. Partially sighted means that the person has some difficulty in seeing and reading information, and requires special assistance with learning and reading. Low vision indicates a more serious visual impairment, where reading at normal distances is not possible. People with low vision have to use supportive tools to read and see in their environments. They may even learn through the use of Braille. Legally blind refers to a vision less than $20 / 200$ and a limited range of vision. People who are legally blind cannot see things clearly, whether it is near or far. Totally blind means that the person has no vision at all. Their eyes are not able to process images, and they learn through non visual resources, including Braille.

According to WHO (2012), globally the major causes of visual impairment are: uncorrected refractive errors (myopia, hyperopic or astigmatism) (43\%), cataract, (33\%) and glaucoma (2\%). Besides, the age at which they become visually impairment also affects their needs. Students who were born visual impaired has different needs with students who lose their sight during their childhood or teenage.

Considering that each student with visual impairment has different learning needs, therefore, it is necessary for lecturers to know the types and causes experienced by student with visual impairment in the beginning of instructional process. So, the lecturers can choose appropriate instructional design in their classrooms.

\section{Instructional Design}

According to Reigeluth (1983) in Prawiradilaga (2007: 15), Instructional design is the outline of learning theories application to facilitate learning process. In addition, Gagne, Briggs \& wager (1992) states that instructional design helps learning process in short and long term (Prawiradilaga, 2007: 15). Based on this concept, instructional design is considered as basic thinking in one systematic 
system that includes analysis, design, development, implementation and evaluation (Dick, Carey \& Carey, 2005 in Prawiradilaga, 2007: 16). Instructional design is an important aspect in learning because it can improves the quality of learning to be a meaningful learning. It is also based on students' character and personal condition (Hamzah Uno, et al. 2010: 7-11). In conclusion, instructional design is an effort to create effective learning method to achieve learning goal.

There are 4 components in instructional design such as students, learning objective, method and assessment. In terms of students, instructional design should consider the background of learners, for example: level of competency, physical condition, motivation and learning style. By analyzing students' background, lectures can develop learning objectives based on students' ability and speed so that students can master certain skill in one set of activity. After analyzing students and developing specific learning objective, appropriate method can also support the effectiveness of instructional design. Method is related to learning strategies, for example: technique in presenting material in the class. The last component is assessment. This component becomes an indicator of students' achievement in the class after mastering the lesson. Assessment can be conducted by doing formative test (ongoing test), summative test (final test), observation, survey or interview (Prawiradilaga, 2007:17-18). Based on the components of instructional design, it can be summarized that instructional design has three characters: a) student- centered learning; b) systematic and c) empiric.

\section{English Learning for Students with Visual Impairment}

Few years ago, students with visual impairments were placed in a special school for blind students and did not get any opportunity to attain higher education. Now, they can study together with sighted or normal students in regular school or university. Placing students with special needs in regular classroom is called inclusive education.

Dealing with students with visual impairments in our classroom is not a big matter as long as the lecturers know how to communicate with them. The lecturer and other students should understand the most appropriate ways to accommodate students with visual impairments in the classroom as well as in examination.

According to four aspects in instructional design (students, learning objective, method and assessment), our discussion is narrowed to specific 
instructional design in English learning for students with visual impairments. According to the center of SSD (Services for the Students with Disabilities) in the University of Indianapolis (USA), there are several instructional design that can be integrated in learning process, such as: (1) student's physical condition; (2) learning objective; and (3) methods

The first aspect is students' physical condition. The classroom should be set based on their condition. Appropriate seating is important for a visually impaired student; since the student cannot see visual cues, he or she needs to be seated in a position to receive verbal cues. The best seat for him or she is close to the teacher so they can listen to the lecture clearly. The lecturers need to try to speak directly to the class, remember that turning our head away can muffle sound because body language and gestures cannot be seen. Besides, it necessary to control background noise since it will distract visually impaired student's attention.

The second aspect is learning objective. The most potential English skill that they can master well is listening and speaking because a student with vision impairment has sight problem, not hearing loss. Use their ability to deliver most of the content. Use general vocabularies to explain the lesson. Do not hesitate to use words such as look or see; students with vision impairments use these terms too.

The third aspect is methods. In doing the learning process, lectures can integrate some methods and media. The lecturers can use various media, especially audio media (audio recording, speech or lecture) to support learning process. Lectures also can ask students about learning aids that they may need during the process. Moreover, arrange computer lab accessibility with IT technician and disable center (multimedia-based learning). Allow student to work with a partner or allow a volunteer in the class to support the student (team work). Make sure the materials are organized and easily accessed by the student. Allow student to record result verbally instead of writing them. Verbalize every writings on the white board and spell every technical term.

This is in line with Rofah, et al (2010a: 42) that states that lecturer should accommodate learning needs of students with visual impairment who use different aids suitable for their disabilities and resources that they have. She said that lecturers should give soft copy of teaching material to students with visual impairment, give reference lists beforehand because they need longer time to 
access information. Lecturer should narrate visual teaching materials and avoid too much visual content in teaching material. In addition, lecturer should consider outdoor activity (field trip, interview) if it is regarded as problem for students with visual impairment to deal with.

Rofah, et al (2010b: 41) also said that learning method for students with visual impairment should be cooperative learning instead of competitive learning. Competitive learning will make students with visual impairment loss their self confident and are possibly left behind by student without visual impairment.

Adaptation in assessment and examination for students with visual impairment must be considered, too. Assessment and examination are very useful for teacher to evaluate and find out students' development and achievement. There are some adaptations, as follow: (a) Choose appropriate test type. Lectures can choose test type such as oral test by using interview or listening test by using audio. Besides, it is better to make close books examination instead of open book because it will be difficult for students with visual impairment to access their literatures ;(b) Tests can be administered by having the questions read to the students by a volunteer or assistant. The assistant will read and write for the blind students. However, in English exam, it will be problematic when the assistant does not have good proficiency in English. Both the students and the assistant will get into trouble;(c) if the students can access computer with JAWS, they can get independent test. The lecturer just need to give the exam in soft files to the students, then they can 'read' it independently in their computer ;(d) Reproduce exams in a large print if the student has a low vision. (e) Allow extra time (about 20-50\% longer) for test taking in a separate and quiet setting.

Regarding some adjustment in classroom accommodation and testing adaptation for students with visual impairment, it is necessary to discuss classroom accommodations and testing adaptations early in the semester (within the first couple of class days) with them. The lecturer should understand need analysis of students with visual impairment.

\section{Case Study}

\section{Case Study 1}

This study class was taken from an English class in a university level. This class is an inclusive class where the sighted student and disable student study in the 
same room. Rini (name changed to protect privacy) was a student with visual impairment but she studied English in a regular English class with other sighted students. She got her blindness since she was a little baby. She got a high fever that has damaged her brain nerve. Therefore, she has never seen the color of the world, so it is difficult for her to imagine things, color, etc.

Before enrolling inclusive university, Rini used to study in a special school for the blind. However, since English is one of her favorite subject, she learnt English by herself. She loves English songs. She likes to listen to English news, and read English Braille where she studied grammar from. She also has a Braille English dictionary, so she can learn many vocabularies. When she was in high school, she used to talk in English with her teacher. Therefore, her level of English proficiency is much higher than the other students.

Rini was an open-minded and helpful student. She is also a highly motivated student. She didn't hesitate to ask her lecturer to help her in learning. This open attitude motivated her lecture to make some adaptation in classroom setting and material, for instance: special guidance for him, peer learning and learning through games.

Since Rini cannot see things, imageries do not mean a lot to her. Instead of writing the material, the lectures should read and explain the material in a loud voice. While other students in the classroom can understand what is written on the whiteboard, she needs to have it read out loud by the lecture or her friends. When other students can read and practice exercises in their academic books, she would have it read by a colleague in order to accomplish the exercise. When other students can easily take notes and write their exercise in pieces of paper, she needs to transform it into Braille symbols. Otherwise, it will be difficult for her to recall the materials. It takes longer time for her to hole her papers to make Braille symbols. Therefore, the lecture should give extra time to her when she needed to transform material to Braille symbols.

The lecturer should use descriptive instruction expression to explain some situations, for example: left, right, in front of, besides, behind, etc. The use of "this" or "that" must be refrained because it does not make any sense for students with visual impairment. When explaining preposition of place and movement, the use of media such as ball or toys can make explanation clearer. It is necessary to provide 
student with a copy of vocabulary words, definitions and examples ahead of time in either soft copy or Braille, so she is familiar with concepts as they are introduced.

Surprisingly, Rini could present her work in a written text. In fact, she can access and operate computer program. She said that she got computer course special for blind student at difable center in this university at the beginning of her study. So, she can type well. She can also read typed material since she has an adaptive computer using JAWS software which reads out loud the screen. The lecturer just needs to provide soft copy for all materials so she could access it by using JAWS. She can access it on her personal computer or in the difabel corner at university library. Her friends always helped her to access the materials.

The presence of friends assistant is extremely meaningful for Rini. Therefore, the lecturer allows her to work with a partner or allow a volunteer in the class to support her in doing some exercises in the class. The assistant also helped her to read and write for her. However, since she can use adaptive computer with JAWS, she did not need any assistant in doing her exam. She just need a personal computer with JAWS and does her exam herself.

Working in group could be fun and meaningful for Rini. The lecturer can involve her in discussion group and solve problems together with the other students. Rini's English proficiency is better than her peers in the class. The lecturer used this advantage to ask her to help by leading discussion group and solve problems together with the other students. In reading groups, she has the directive to check the other students' pronunciation or to translate. Then, she has, for example, to make a summary of the passage. She enjoys this activity because she is admitted by her classmates, she is learning as well, and is not bored. Moreover, by joining discussion groups, all students become closer and bound better.

In verbal communication, intonation may give different meaning on the same sentence. So, the lecturer should use pleasant intonation and sense of humor to build chemistry in communication. In terms of body behavior and verbal communication, students in general can actually feel the teacher's emotions through gestures, and it affects learning awareness. A teacher who is funny, warm and smiley, with a passionate soul would influence students to work better. With Rini, the contact through a smile happened with a clear and pleasant intonation and sense of humor. 
There are many ways to lower learner's anxiety, such as jokes and laughter, games, and movie. This strategy focuses on activities learners can enjoy and laugh together. What lecturers need to do is employ any meaningful activities in class in which Rini can enjoy and share laughter with her friends. One of the activities is, as mentioned above, by using games. Ur $(1988 ; 23)$ said that games are interesting for they provide a feeling of pleasurable tension. When a lecturer just explains the materials, asks the students to do exercise and exercise, gives drilling and always corrects the students' mistakes, the students will be stressful and will not enjoy the class. This will be an obstacle in achieving the goal in the class. But, when the students play games in the class, they will have fun and can relax. If they are free from worry and stress, they will be able to acquire the subject more effectively.

Rini also likes playing games. However, the lecturer should apply appropriate games that can be appropriate with Rini's condition, for example: whispering some vocabularies, index card, bingo; and snake and ladder. Rini could play whispering games easily since she didn't have any problem in hearing, so she could transfer information which she heard to her peers. Index card match was also an easy game for her since she just held the paper and her peers tried to find out their pairs. After she found her partner, then she creates the sentence with her partner. In playing some board games such as bingo and snake and ladder, she participated in throwing the dice and her peers would help her to read the instruction. She also enjoyed miming games like Simon says. Although sometimes she found difficulties, however, she could enjoy the games and share her laughter with her peers.

By adapting some classroom setting and material, the lecturer could see some positive achievements in Rini's learning, for instance: a) Rini could study English well in the class and share her English comprehension to her friends; (b) Rini could present her work in a written text. In fact, she has learned to use computer during her study in the university. She used adaptive computer which has special software called JAWS, software that can read out loud all the words on the computer screens.

\section{Case Study 2}

Second case study was also taken in inclusive English class with different ability of student. Tono (name changed to protect privacy) got blindness due to a terrible accident that has injured his head when he was 9 years old. Due to his 
blindness history, his parents are overprotective toward him. As a result, he becomes very dependable person. Moreover, he got some difficulties in adaptation with his new environment in university.

Tono had a good motivation in learning English. Generally, he was willing to be active in the class, for example: participating in interactive dialog by repeating what his friends said. However, he had low achievement in the class because of some factors, for example: low basic knowledge in English, limited English vocabularies, and low ability in understanding concept.

In terms of low basic knowledge in English, Tono used to study in a special school for the blind students where English was not taught as intensive as in regular school. So, his understanding in English is very low. Besides, he also had limited vocabularies since he is not accustomed to use English words. He also had limited ability to use computer as a media to study English (with or without specific software for visual impairment). Meanwhile other students with visual impairment in this university can access their learning materials such as e-books, documents, etc using JAWS (software that can read out loud all the words) in their personal computer or in difable corner, Tono just could turn on/off his computer. So, giving soft files to support his study is insignificant for him.

As the impact of this condition, he could not study by his own. He needed someone to help him. The lecturer has appointed his classmate to be an assistant in order to help him during the classes. His assistant helped him to read and write his written assignment. In addition, his assistant also taught him to spell English words. When he got homework, he asked someone to help him. Unfortunately, the person who helped him at home does not have good ability in English.

Third, Tono had low ability in understanding concept because of low memory process. It is related to the cause of his blindness. When he was a child, he got an accident that damaged his brain nerve. However, since he ever got an opportunity to see the world, he can imagine colors, things, alphabets and numbers.

In spite of these problems, all of his friends always helped him in doing most of the activities in the class, for example: read the reading material for him or read the exercises for him, especially for speaking practice. Based on this condition, the lecturer decided to make some adjustments to help him to study English, for instance: organizing physical environment, special guidance for him, peer learning and learning through games. 
In organizing physical environment, lecture involves some attempts, such as : conditioning his seat, his position to the lecturer and class atmosphere. He needs a proper seat where he can listen to the lecturer clearly. Thus, it is necessary to set his seat and his position close to the lecturer. Conditioning class atmosphere means setting other students' activities to avoid any disturbance that might distract him from his learning focus. Even other friends' chatting can distract him from listening to the lecture. Lecturer also provided or did special guidance for him, for example: spoke louder, closer and slower to him. The lecturer should try to speak directly to the student with visual impairment and address him or her by name. Otherwise, he would not aware that the lecturer was talking to him. Sometimes, the lecture should spell the word or explain the meaning one by one. Then, he writes important vocabularies in Braille.

Switching to mother tongue is basically strategy used in speaking. It is very helpful when his lecturer or assistant explain theories or vocabularies. This strategy is called code-switching. In single conversation, two-codes or two languages are used in conversation. Generally, English is used as main language in the classroom. However, when there is word or phrase that is difficult to understand, students use Indonesia language.

Moreover, peer learning method is very useful in this case. While his lecturer could not assist him during the class activity, his peers could do so. The lecturer can assign one student who had good proficiency in English to be the assistant to help Tono during the lesson hour. The assistant should read, write and explain the materials for him. Moreover he has ever said that his assistant could explain clearer when he got difficulty in catching what the lecturer explained. In addition, since he could not access the computer using JAWS, the assistant also help him to read and mark the answer sheet during a test. This assistance was very usual for that time. Sometimes it happened naturally without lecturer's instruction. On the contrary, group work method is not too meaningful for Tono. Although he can discuss about topics of grammar or reading comprehension in his group, however, it seems that he got difficulty to follow the discussion when some friends talk in the same time. Moreover, not all of his friend in the class can assist him as well as his assistant. As a result, he just kept silent during the discussion. So, when other friends were discussing in groups of 3-5 students, Tono preferred to discuss in pair with his assistant

In case of games, lecture use simple games which are suitable for students 
with visual impairment in the class, for example: whispering, Simon says, circle movement, snake and ladder and throw and catch. He really liked the games. He involved in the games by doing the things that he could do such as make a sentence, follow the instruction, etc.

Creating pleasant and enjoyable learning methods in appropriate way is a challenge for lecturer to keep Tono's motivation in track. He has good motivation in learning English. He enjoyed most activities in English class. However, sometimes he lost his motivation when he thought the material is too difficult for him to deal with. Besides, he seemed distressed when the lecturer was to fast in delivering teaching materials. On the other hand, serious and monotonous teaching and learning methods would make Tono sleepy because he could not see lecturer's gestures or other students' movement.

As the impact of the efforts above, Tono could enjoy the classroom activity. The point of these efforts was involving him to do as much as he could do with other sighted student. However, he could do some more practices to gain a better understanding in English and improving his ability in using various kinds of media that could help him to learn English.

\section{CONCLUSIONAND SUGGESTION}

Students with visual impairment can have similar motivation to sighted students, especially in learning English. Lecturers should appreciate this motivation in designing special instructional procedures for them. The focus of the learning process does not only present the material but also motivate and support them so they can maximize their learning.

Before designing the instructional design, lectures should analyze students' character based on their physical condition and learning problems so that lecturers can determine the appropriate strategy to support the learning process.

\section{REFERENCES:}

Anonymous, 2009. Information for Students who are Blind or Visually Impaired retrieved from http://www.uindy.edu/ssd on October 2009.

Burton M., Knipe C., Midtal V., Rathwell R and Wong F, 2009. Reading Strategies 
for Students with Visual Impairments: A Classroom Teacher's Guide retrieved from http://www.setbc.org on May 2012.

Carney, Susan et.al. 2001. Teaching Students with Visual Impairments. Retrieved from http://www.education.gov.sk.ca/vision on 01 May 2013.

Hamzah Uno, Lamatenggo, N. \& Satria Koni. 2010. Desain Pembelajaran. Bandung: MQS Publishing.

http://www.ehow.com/about_5052348_definition-visually-impaired.html. Visual Impairment Definition. by Naima Kamal. Retrieved on 01 July 2012.

http://www.hoagiesgifted.org/eric/e653.html. Educating Students with Visual Impairments. The ERIC Clearinghouse on Disabilities and Gifted Education (ERIC EC). Retrieved on 01 July 2012.

http://www.open.ac.uk/inclusiveteaching/pages/understanding-and-awareness/ what-is-visual-impairment.php Making your teaching inclusive by Alan. The Open University. Retrieved on 01 July 2012.

http://www.who.int/mediacentre/factsheets/fs282/en/ Visual Impairment and Blindness. WHO Media Centre. Retrieved at 30 June 2012.

Manal, Naima. 2012. Visual Impairment Definition. Retrieved from http://www.ehow.com/about_4793004_visual-impairment-definition.html on 1 May 2013

Prawiradilaga, D.S. 2007. Prinsip Desain Pembelajaran. Jakarta: Prenada Media Group.

Rofah, Andayani and Muhrisun. 2010a. Membangun Kampus Inklusif. Best Practices Pengorganisasian Unit Layanan Difabel. Yogyakarta: Pusat Studi Lananan Difabel (PSLD) UIN Sunan Kalijaga

Rofah, Andayani and Muhrisun. 2010b. Inklusi pada Pendidikan Tinggi. Best Practices PembelajarandanPelayanan Adaptif Bagi Mahasiswa Difabel Netra. Yogyakarta: Pusat Studi Lananan Difabel (PSLD) UIN Sunan Kalijaga 